\title{
Orest Krasivski
}

https://orcid.org/0000-0002-7028-6038

(Gniezno)

\section{MECHANIZMY POGŁĘBIANIA KOMUNIKACJI POLITYCZNEJ W UKŁADZIE O STOWARZYSZENIU MIĘDZY UKRAINA A UNIĄ EUROPEJSKĄ}

\section{Abstract}

The paper discusses the role of the Association Agreement in deepening political communication between Ukraine and the EU. The author highlights the role of political communication in shaping the political association between Ukraine and the EU, and analyzes instances of such communication within the framework of the Ukraine-EU summits, Association Council, Association Committee, Parliamentary Committee of the Association and Civil Society Platform is analyzed. As a result, the chief issues affecting political communication between Ukraine and the EU are revealed.

\section{Key words}

European integration, Association Agreement, political association, political communication 
Z perspektywy ukraińskiej integracja europejska oraz przygotowania do ewentualnego członkostwa w Unii Europejskiej determinowane są przez interes narodowy oraz określane na poziomie legislacyjnym. Ważnym krokiem w kierunku integracji Ukrainy z UE jest wdrożenie Układu o stowarzyszeniu między Ukrainą a UE. Szczególnie interesująca jest polityczna część Układu, która zakłada utworzenie stowarzyszenia politycznego między Ukrainą a UE, radykalną reformę administracji publicznej, sektora bezpieczeństwa i systemu egzekwowania prawa. Sukces stowarzyszenia politycznego bezpośrednio zależy natomiast od komunikacji politycznej między Ukrainą a UE ${ }^{1}$.

Celem artykułu jest analiza komunikacji politycznej między Ukrainą a UE w ramach realizacji Układu o stowarzyszeniu oraz określenie problemów, które mogą stanąć na drodze do integracji europejskiej Ukrainy. Przez komunikację polityczną rozumie się tu proces wzajemnych oddziaływań o charakterze informacyjnym zachodzących pomiędzy podmiotami polityki połączonymi relacjami władzy i współpracy.

Układ o stowarzyszeniu ma na celu przede wszystkim rozwój i wzmocnienie komunikacji politycznej między Ukrainą a UE. Układ zakłada realizację następujących celów: a) pogłębianie stowarzyszenia politycznego oraz większe zbliżenie i skuteczność w zakresie polityki bezpieczeństwa; b) propagowanie stabilności i bezpieczeństwa międzynarodowego w oparciu o skuteczne działania wielostronne; c) wzmocnienie współpracy i dialogu między Stronami w dziedzinie międzynarodowego bezpieczeństwa i zarządzania kryzysowego, w szczególności $\mathrm{w}$ celu rozwiązywania światowych i regionalnych problemów oraz głównych zagrożeń; d) zwiększenie nakierowanej na wyniki, praktycznej współpracy między Stronami na rzecz osiągnięcia pokoju, bezpieczeństwa i stabilności na kontynencie europejskim; e) zwiększenie poszanowania zasad demokratycznych, praworządności i dobrych rządów, praw człowieka i podstawowych wolności, w tym praw osób należących do mniejszości narodowych, niedyskryminacji osób należących do mniejszości i poszanowania różnorodności oraz przyczynianie się do konsolidacji krajowych reform politycznych; f) rozwijanie dialogu i pogłębienie współpracy między Stronami w dziedzinie bezpieczeństwa i obrony; g) promowanie zasad niezależności, suwerenności, integralności terytorialnej i nienaruszalności granic².

W dokumentach i literaturze naukowej nie ma jednej definicji „stowarzyszenia politycznego". Stowarzyszenie polityczne między Ukrainą a UE jest

\footnotetext{
${ }^{1}$ O relacjach Unii Europejskiej i Ukrainy szerzej: Krasiwski 2016, s. 175-230.

${ }^{2}$ Uhoda pro asotsiatsiiu mizh Ukrainoiu.
} 
dobrowolnym związkiem (sojuszem) w celu osiągnięcia zbliżenia w kwestiach polityki zagranicznej i bezpieczeństwa, w oparciu o wzajemnie korzystną współpracę, przy jednoczesnym zachowaniu suwerenności podmiotów, niezależności politycznej oraz prawnej stron Układu o stowarzyszeniu. Jako że ukraińsko-unijne stowarzyszenie polityczne opiera się na wartościach europejskich, Ukraina zobowiązała się do przeprowadzenia reform wewnętrznych w celu pogłębienia przemian demokratycznych, zapewnienia praworządności oraz poszanowania praw człowieka i podstawowych wolności. Układ o stowarzyszeniu to format Inicjatywy Partnerstwa Wschodniego, które funkcjonuje w ramach unijnej Polityki Sąsiedztwa z 2003 r. Polityka Sąsiedztwa ma na celu zwiększenie bezpieczeństwa poprzez stworzenie „kręgu przyjaciół”, "pasa dobrobytu” z sąsiednimi krajami w całej Unii Europejskiej na Wschodzie (Ukraina, Mołdawia, Gruzja, Białoruś) i na Południu (Algieria, Egipt, Izrael, Jordania, Liban, Libia, Maroko, Palestyna, Syria, Tunezja) ${ }^{3}$.

Komunikacja polityczna między Ukrainą a UE odbywa się w ramach szczytów Ukraina-UE, Rady Stowarzyszenia, Komitetu Stowarzyszenia, Komitetu Parlamentarnego Stowarzyszenia oraz Platformy Społeczeństwa Obywatelskiego. Te organy dwustronne zostały powołane na mocy Układu o stowarzyszeniu. Komunikacja polityczna może również odbywać się w innych formatach: a) regularnych posiedzeń na szczeblu dyrektorów politycznych, komisji politycznej i bezpieczeństwa oraz na szczeblu ekspertów, w tym podczas dotyczących poszczególnych regionów lub konkretnych kwestii oraz posiedzeń przedstawicieli Unii Europejskiej, z jednej strony, i przedstawicieli Ukrainy, z drugiej strony; b) wykorzystania wszystkich kanałów dyplomatycznych i wojskowych między Stronami, w tym odpowiednich kontaktów dyplomatycznych i wojskowych między Stronami, odpowiednich kontaktów w państwach trzecich oraz ONZ, OBWE i innych forach międzynarodowych; c) regularnych posiedzeń zarówno na szczeblu wysokich urzędników, jak i ekspertów instytucji wojskowych $\mathrm{z}$ obu Stron; d) w każdy inny sposób, w tym podczas spotkań na szczeblu ekspertów, które przyczyniałyby się do poprawy i konsolidacji tego dialogu ${ }^{4}$.

Najwyższym szczeblem merytorycznej komunikacji politycznej między stronami są spotkania na szczycie. Spotkania na szczycie odbywają się, co do zasady, raz do roku. W trakcie spotkań na szczycie formułowane są ogólne wytyczne w zakresie wdrażania Układu o stowarzyszeniu; spotkania na

\footnotetext{
${ }^{3}$ Yavorska H. Shchodo samitu „Skhidnoho partnerstwa”.

${ }^{4}$ Uhoda pro asotsiatsiiu mizh Ukrainoiu.
} 
szczycie stwarzają również możliwość dyskusji na temat kwestii dwustronnych lub międzynarodowych, będących przedmiotem wspólnego zainteresowania. Po ratyfikacji Układu o stowarzyszeniu odbyły się cztery takie spotkania ${ }^{5}$.

Pierwszy szczyt Ukraina-UE w ramach Układu o stowarzyszeniu odbył się 27 kwietnia 2015 r. w Kijowie. Rozmowy dotyczyły nowych okoliczności i zagrożenia bezpieczeństwa w kontekście agresji rosyjskiej wobec Ukrainy i działań rosyjskich podważających zasady prawa międzynarodowego i bezpieczeństwa europejskiego. Omówiono kompleks zagadnień związanych z realizacją porozumień mińskich i konsekwencjami okupacji Autonomicznej Republiki Krymu i miasta Sewastopol. Strony dyskutowały na temat wdrażania układu stowarzyszeniowego i reform wewnętrznych na Ukrainie, procesu przygotowań do szczytu $\mathrm{w}$ Rydze $\mathrm{w}$ ramach Inicjatywy Partnerstwa Wschodniego, a także kwestii regionalnej. UE dała wyraźne sygnały poparcia dla niepodległości, suwerenności i integralności terytorialnej Ukrainy, wysiłku państwa w zakresie przeciwdziałania agresji zbrojnej Federacji Rosyjskiej, w szczególności w kontekście kontynuacji polityki sankcji UE, a także procesu wdrażania reform wewnętrznych i stabilizacji wewnętrznej sytuacji gospodarczej ${ }^{6}$. Po szczycie zatwierdzono wspólne oświadczenie.

Podczas drugiego szczytu Ukraina-UE, który odbył się 24 listopada 2016 r. w Brukseli, omówiono szereg zagadnień związanych z rozwojem sytuacji we wschodniej Ukrainie, wdrażaniem porozumień mińskich oraz rosyjską okupacją Krymu. Rozmawiano o procesie realizacji Układu o stowarzyszeniu i reform wewnętrznych na Ukrainie, a także o zapewnieniu odpowiedniego wsparcia ze strony UE. Szczególną uwagę poświęcono zakończeniu procesu ratyfikacji Układu o stowarzyszeniu, perspektywom wprowadzenia ruchu bezwizowego dla obywateli Ukrainy, współpracy w dziedzinie energetyki, wdrożeniu pogłębionej i kompleksowej strefy wolnego handlu (porozumienie o wolnym handlu). Podczas szczytu ukraińskiego potwierdzono dalsze wsparcie ze strony UE dla niezależności, suwerenności i integralności terytorialnej Ukrainy, a także wdrażania jej wewnętrznych reform. Aby przeciwdziałać zewnętrznej agresji Rosji, kontynuowano politykę sankcji UE wobec Rosji. Osiągnięto wysoki postęp w zakresie wdrażania krajowych reform i stabilizacji sytuacji finansowej i gospodarczej na Ukrainie ${ }^{7}$.

Trzeci szczyt UE-Ukraina, w dniach 12-13 lipca 2017 roku w Kijowie, był zakończeniem pierwszego etapu realizacji układu o stowarzyszeniu między

\footnotetext{
${ }^{5}$ Stan na 2017 rok.

${ }^{6}$ Ruda 2015.

${ }^{7}$ Pidsumky samitu Ukraina-JS.
} 
Ukrainą a UE. Szczególną uwagę zwrócono na zakończenie procesu ratyfikacji Układu o stowarzyszeniu, wejście w życie ruchu bezwizowego Ukraińców, współpracę w dziedzinie energetyki, wdrażania strefy wolnego handlu. Poruszone zostały również kwestie związane z sytuacją we wschodniej Ukrainie, realizacją porozumień mińskich i rosyjską okupacją Krymu i Sewastopola. Omówiono też postępy w realizacji układu o stowarzyszeniu i reform wewnętrznych na Ukrainie oraz zapewnienie odpowiedniego wsparcia ze strony UE ${ }^{8}$.

Należy zauważyć, że przygotowania do szczytu z 2017 r. odbyły się w trudnych warunkach, po tym, jak obywatele Holandii w referendum w 2016 r. zagłosowali przeciwko ratyfikacji Układu o stowarzyszeniu między Ukrainą a UE. Holenderski parlament ratyfikował jednak Układ o stowarzyszeniu, pod warunkiem przyjęcia przez UE konkluzji Rady Europejskiej, gdzie zaznaczono:

\begin{abstract}
Mając na celu ustanowienie bliskich i trwałych stosunków między Stronami Układu w oparciu o wspólne wartości, Układ nie nadaje Ukrainie statusu kraju kandydującego do przystąpienia do Unii, ani nie stanowi zobowiązania do nadania Ukrainie takiego statusu w przyszłości. Układ potwierdza współpracę z Ukrainą $\mathrm{w}$ dziedzinie bezpieczeństwa, przede wszystkim $\mathrm{w}$ odniesieniu do zapobiegania konfliktom, zarządzania kryzysowego i nierozprzestrzeniania broni masowego rażenia. Nie nakłada on na Unię ani jej państwa członkowskie obowiązku zapewnienia Ukrainie zbiorowych gwarancji bezpieczeństwa lub innej pomocy wojskowej lub wsparcia wojskowego. Określając cel polegający na ułatwianiu przemieszczania się obywateli, Układ nie przyznaje obywatelom Ukrainy ani obywatelom Unii, odpowiednio, prawa do swobodnego pobytu i podejmowania pracy na terytorium państw członkowskich lub Ukrainy (...). Układ potwierdza zobowiązanie Unii do wspierania procesu reform na Ukrainie. Nie wymaga od państw członkowskich dodatkowego wsparcia finansowego dla Ukrainy?.
\end{abstract}

Taka decyzja Rady Europejskiej w pewnym stopniu niweluje treść Układu o stowarzyszeniu i utrudnia realizację politycznego stowarzyszenia między Ukrainą a UE.

$\mathrm{Na}$ czwartym szczycie w Brukseli w dniu 9 lipca 2018 r. strony przyjęly wspólne oświadczenie. W oświadczeniu UE podkreśliła swoją solidarność wobec Ukrainy, jej niepodległości i integralności terytorialnej, oraz potwierdziła, że czas obowiązywania sankcji gospodarczych wobec Rosji pozostaje ściśle związany z pełną realizacją porozumień mińskich. Ponadto UE uznała europejskie aspiracje Ukrainy i pogratulowała tego wyboru. Wskazano, że należy kontynuować reformy w dziedzinie opieki zdrowotnej, systemu emerytalnego, decentralizacji, administracji publicznej, zamówień publicznych,

\footnotetext{
${ }^{8}$ 19-j Samit Ukraina Yevropeiskyj Sojuz.

${ }^{9}$ Opublikovano tekst rishennia EU shchodo Uhody pro asotsiatsiiu z Ukrainoiu.
} 
ochrony środowiska itp. Przywódcy UE potwierdzili rolę Ukrainy jako państwa strategicznego dla tranzytu i dostaw gazu ziemnego ${ }^{10}$. W ramach szczytu między Ukrainą a Europejskim Bankiem Inwestycyjnym zawarta została umowa pożyczki o wartości 75 milionów euro na projekty związane z bezpieczeństwem dróg miejskich w pięciu ukraińskich miastach: Dnieprze, Charkowie, Kijowie, Lwowie i Odessie.

Nadzór i kontrolę nad realizacją Umowy sprawuje Rada Stowarzyszenia, monitoruje ona funkcjonowanie Umowy w kontekście założonych celów. Rada Stowarzyszenia może rozważyć ważne kwestie wynikające z Układu i wszelkie inne kwestie będące przedmiotem wspólnego zainteresowania. Spotkania Rady Stowarzyszenia odbywają się na szczeblu ministerialnym, co najmniej raz do roku, a także w sytuacji, gdy wymagają tego okoliczności. Składa się ona z członków rządu Ukrainy i członków Unii Europejskiej oraz Komisji Europejskiej. Strony przewodniczą Radzie Stowarzyszenia na przemian. Rada Stowarzyszenia jest uprawniona do podejmowania decyzji, które są wiążące dla stron. Rada może wprowadzać zmiany w załącznikach do Układu, biorąc pod uwagę rozwój prawa $\mathrm{UE}^{11}$.

Pierwsze spotkanie Rady Stowarzyszenia UE i Ukrainy odbyło się 15 grudnia 2014 roku w Brukseli. Na tym spotkaniu, w celu zapewnienia pracy dwustronnych organów Stowarzyszenia, przyjęta została decyzja Rady Stowarzyszenia w sprawie regulaminów Rady Stowarzyszenia, Komitetu Stowarzyszenia i jego podkomitetów, ustanowienia dwóch podkomitetów (Podkomitet ds. wolności, bezpieczeństwa i sprawiedliwości i Podkomitet ds. współpracy gospodarczej i w innych sektorach), oraz przekazania niektórych uprawnień przez Radę Stowarzyszenia Komitetowi Stowarzyszenia w składzie rozstrzygającym kwestie dotyczące handlü ${ }^{12}$.

Rada Stowarzyszenia UE-Ukraina zatwierdziła zaktualizowany program stowarzyszeniowy w formie wymiany listów. Zaktualizowany program stowarzyszeniowy określił dziesięć krótkoterminowych priorytetów w zakresie reform politycznych, sądownictwa, systemu wyborczego, antykorupcyjnych, administracji publicznej, energetycznych, deregulacyjnych, zamówień publicznych, podatków i kontroli zewnętrznej, które mają dla Ukrainy pierwszorzędne znaczenie. Program ten jest głównym narzędziem oceny i monitorowania

\footnotetext{
${ }^{10}$ Daidzhest novyn $\mathrm{z}$ yevrointehratsii, Yevropeiskoho Soiuzu ta Skhidnoho Partnerstva za 26 chervnia - 15 lypnia $2018 \mathrm{r}$.

${ }^{11}$ Pytannia pidhotovky ta provedennia zasidan okremykh dvostoronnikh orhaniv asotsiatsii mizh Ukrainoiu ta EU.

${ }^{12}$ Rishennia № 3/2014 Rady asotsiatsii mizh Ukrainoiu ta EU vid 15 hrudnia 2014 r.
} 
postępów Ukrainy w realizacji układu stowarzyszeniowego, w tym osiągnięcie celów stowarzyszenia politycznego i integracji gospodarczej. Przewiduje się, że UE zapewni Ukrainie wsparcie w realizacji programu stowarzyszeniowego poprzez wykorzystanie wszystkich dostępnych zasobów pomocy UE, a także wymianę doświadczeń, rozpowszechnianie najlepszych praktyk i know-how.

Drugie posiedzenie Rady Stowarzyszenia odbyło się 7 grudnia 2015 r. Uczestnicy spotkania potwierdzili gotowość stron do rozpoczęcia, od 1 stycznia 2016 r., tymczasowego stosowania Układu o stowarzyszeniu w ramach pogłębionej i kompleksowej strefy wolnego handlu, do kontynuowania współpracy w dziedzinie bezpieczeństwa energetycznego. Strony omówiły perspektywy zakończenia drugiego etapu planu działania na rzecz liberalizacji systemu wizowego dla Ukrainy, dalszego udziału Ukrainy w programach i inicjatywach UE, wyniki Europejskiej Polityki Sąsiedztwa. W ramach spotkania podpisano porozumienie administracyjne między Ministerstwem Obrony Ukrainy a Europejską Agencją Obrony. Główne wyniki dyskusji i osiągnięte porozumienie zostały przedstawione przez strony we wspólnym komunikacie prasowym ${ }^{13}$.

Z udziałem członków rządu Ukrainy i Rady Unii Europejskiej i Komisji Europejskiej, 19 grudnia 2016 roku w Brukseli odbyło się trzecie spotkanie stowarzyszenia. Spotkanie było pierwszym od początku funkcjonowania Strefy Wolnego Handlu (DCFTA) 1 stycznia 2016 r., dlatego omówiono nie tylko stan wdrożenia Układu o stowarzyszeniu jako całości, ale także pierwsze wyniki wdrażania DCFTA. Strona UE potwierdziła gotowość rozszerzenia dostępu ukraińskich towarów na rynek europejski, w szczególności poprzez dodatkowe preferencje autonomiczne, ale jednocześnie uznała potrzebę poprawy klimatu biznesowego i inwestycyjnego na Ukrainie. UE potwierdziła również gotowość udzielenia Ukrainie dalszej pomocy finansowej i technicznej w procesie wdrażania systemowych reform politycznych i gospodarczych, zgodnie ze wspólnymi zobowiązaniami. W ramach spotkania podpisano pięć umów między Ukrainą a UE, w szczególności umowę o finansowaniu służby publicznej, cztery umowy dotyczące finansowania programów współpracy transgranicznej. Ponadto podpisano szereg dokumentów dotyczących funduszy kredytowych z Europejskiego Banku Inwestycyjnego ${ }^{14}$.

${ }^{13}$ Spilnyi pres-reliz pislia zustrichi Rady asotsiatsii mizh Yevropeiskym Soiuzom i Ukrainoiu (7/12/2015).

${ }^{14}$ Spilnyi pres-reliz pislia zustrichi Rady asotsiatsii mizh Yevropeiskym Soiuzom i Ukrainoiu (19/12/2016). 
Czwarte posiedzenie Rady Stowarzyszenia UE-Ukraina odbyło się 8 grudnia 2017 r. w Brukseli. Strony podsumowały postępy w zakresie realizacji Układu i przeprowadzaniu reform oraz podkreśliły potrzebę ich rewitalizacji. Omówiono propozycję Ukrainy dotyczącą dalszej integracji z Unią Energetyczną, Jednolitym Rynkiem Cyfrowym, a także kwestię Unii Celnej między Unią Europejską a Ukrainą. Rada Stowarzyszenia pogratulowała kluczowej roli, jaką społeczeństwo obywatelskie odegrało w walce z korupcją, i zgodziła się, że wymogi dotyczące deklarowania dochodów przez antykorupcyjne organizacje pozarządowe powinny zostać zniesione. Uczestnicy spotkania podkreślili znaczenie utworzenia na Ukrainie wyspecjalizowanego sądu antykorupcyjnego i zagwarantowania jego pełnej niezależności, a także skutecznego mechanizmu weryfikowania elektronicznych deklaracji majątkowych. Rada Stowarzyszenia podkreśliła ważną rolę Ukrainy jako kraju strategicznego dla długoterminowego tranzytu gazu. Podkreślono znaczenie szybkiego podpisania umowy o wspólnym obszarze lotniczym między UE a Ukrainą zgodnie z postanowieniami Układu o stowarzyszeniu. Aby skutecznie wdrożyć Układ o stowarzyszeniu, Rada Stowarzyszenia zgodziła się zintensyfikować dialog między stronami w sprawie aktualizacji załączników do umowy i przyjęcia pilnych map drogowych, aby przybliżyć ustawodawstwo ukraińskie do prawa UE, zgodnie $\mathrm{z}$ wymogami umowy ${ }^{15}$.

W Brukseli w 2017 r. podpisano dwie umowy finansowe. Pierwsza umowa dotyczyła finansowania programu „Wsparcie UE dla Wschodu Ukrainy”. Stwarza ona podstawy prawne do jej realizacji na terytorium Doniecka i Ługańska, pod kontrolą Ukrainy, i przewiduje 50 milionów euro na wzmocnienie zarządzania lokalnego, ożywienie gospodarcze, bezpieczeństwo społeczne i spójność społeczną. Druga umowa dotyczyła finansowania transgranicznego programu na rzecz Dunaju. Na uczestnictwo Ukrainy przeznaczono 5 milionów euro ${ }^{16}$. Projekty współpracy transgranicznej w ramach tego porozumienia mają na celu rozwój społeczno-gospodarczy ukraińskiej części regionu Dunaju (obwody czerniowiecki, odeski, iwano-frankowski i zakarpacki).

W trakcie wykonywania swoich zadań Radę Stowarzyszenia wspiera Komitet Stowarzyszenia (KS) składający się z przedstawicieli Stron, głównie na szczeblu wyższych urzędników, którym przewodniczy z kolei przedstawiciel Ukrainy i przedstawiciel UE. Z ukraińskiej strony członkami Komitetu Stowarzyszenia są wiceministrowie ds. integracji europejskiej, wiceminister

\footnotetext{
${ }^{15}$ Daidzhest novyn z yevrointehratsii, Yevropeiskoho Soiuzu ta Skhidnoho Partnerstva za 1-25 hrudnia $2017 \mathrm{r}$.

${ }^{16}$ Ibidem.
} 
ds. rozwoju gospodarczego i handlu - przedstawiciel handlowy Ukrainy, zastępcy przewodniczących innych centralnych organów wykonawczych, których uprawnienia obejmują wdrażanie umowy ${ }^{17}$. Komitet Stowarzyszenia przygotowuje posiedzenia Rady Stowarzyszenia. Ponadto, Rada Stowarzyszenia może upoważnić Komitet do podejmowania decyzji. Komitet Stowarzyszenia podejmuje swoje decyzje w drodze porozumienia Stron. Komitet Stowarzyszenia zbiera się regularnie co najmniej raz w roku. Komitet Stowarzyszenia organizuje specjalne posiedzenie $\mathrm{w}$ celu rozwiązania wszystkich kwestii związanych z rozdziałem IV Układu „Handel i zagadnienia związane z handlem", czyli kwestią zapewnienia funkcjonowania kompleksowego i pogłębionego obszaru wolnego handlu między Ukrainą a UE.

Komitet Stowarzyszenia wspierają następujące podkomitety: Podkomitet ds. Wolności, Bezpieczeństwa i Sprawiedliwości; Podkomitet ds. Współpracy Gospodarczej i w innych sektorach; Podkomitet ds. Oznaczeń Geograficznych; Podkomitet ds. Zarządzania Sanitarnego i Fitosanitarnego; Podkomitet ds. Współpracy Celnej; Podkomitet ds. Handlu i Zrównoważonego Rozwoju. Posiedzenia Podkomitetu ds. Współpracy Gospodarczej i w innych sektorach planowane są w konfiguracjach zgodnych ze wspólnie określonymi klastrami.

Jako forum dla członków Rady Najwyższej Ukrainy i Parlamentu Europejskiego do organizacji spotkań i wymiany poglądów służy Komitet Parlamentarny Stowarzyszenia (KPS). W skład Komitetu Parlamentarnego wchodzą deputowani Rady Najwyższej Ukrainy i Parlamentu Europejskiego. Organ ten ma prawo żądać od Rady Stowarzyszenia informacji dotyczących wprowadzania w życie Układu o stowarzyszeniu oraz do wydania zaleceń, a także do powoływania odpowiednich podkomitetów ${ }^{18}$.

Podczas dwóch pierwszych posiedzeń Komitetu Parlamentarnego Stowarzyszenia, które odbyły się w dniach 24-25 lutego 2015 r. (Bruksela) i 4-5 listopada 2015 r. (Kijów), parlamentarzyści z udziałem przedstawicieli władzy wykonawczej i społeczeństwa obywatelskiego omówili stan stosunków między Ukrainą a UE, aktualne zagadnienia dotyczące wdrażania Układu o stowarzyszeniu, a także ogólnego bezpieczeństwa i sytuacji politycznej na Ukrainie. Pod koniec sesji zatwierdzono ostateczne oświadczenia i odpowiednie zalecenia ${ }^{19}$.

${ }^{17}$ 4-5 lystopada u Kyievi vidbulos Druhe zasidannia Parlamentskoho komitetu asotsiatsii mizh Ukrainoiu ta EU.

${ }^{18}$ Zakliuchna Zaiava ta Rekomendatsii Pershoho zasidannia Parlamentskoho komitetu asotsiatsii Ukraina - EU.

${ }^{19}$ Ibidem. 
Trzecie posiedzenie Komitetu Parlamentarnego Stowarzyszenia Ukraina-UE odbyło się w dniach 4-25 kwietnia 2016 r. w Brukseli. Uczestnicy spotkania omawiali aktualne zagadnienia stosunków Ukraina-UE, wymieniali poglądy na sytuację polityczną na Ukrainie, sytuację bezpieczeństwa i sytuację humanitarną na Wschodzie Ukrainy i na Krymie, wdrażanie porozumień mińskich, stan wdrożenia Układu o stowarzyszeniu między Ukrainą a UE, początek stosowania DCFTA od 1 stycznia 2016 r., perspektywy wprowadzenia $\mathrm{w}$ tym roku ruchu bezwizowego dla obywateli ukraińskich, wdrożenie reform na Ukrainie i szereg innych kwestii dotyczących współpracy sektorowej. Komitet Parlamentarny Stowarzyszenia postanowił, że należy przedłużyć sankcje wobec Federacji Rosyjskiej aż do pełnej i bezwarunkowej realizacji porozumień mińskich i przywrócenia integralności terytorialnej Ukrainy w ramach międzynarodowo uznanych granic. Po spotkaniu przyjete zostało oświadczenie i zalecenia ${ }^{20}$.

Czwarte posiedzenie Komitetu Parlamentarnego Stowarzyszenia odbyło się w dniach 20-21 września 2016 r. w Kijowie. Uczestnicy omówili aktualne zagadnienia dotyczące stosunków między Ukrainą i UE, wymieniły poglądy na temat reformy instytucjonalnej i decentralizacji, reformy sądownictwa i administracji publicznej, stanu realizacji układu o stowarzyszeniu między Ukrainą i UE, wprowadzenie ruchu bezwizowego dla Ukrainy w najbliższym czasie, realizację reform na Ukrainie oraz szereg innych kwestii współpracy sektorowej. Po zakończeniu przyjęte zostało wspólne oświadczenie i zalecenia.

Piąte posiedzenie Komitetu Parlamentarnego Stowarzyszenia między Ukrainą a UE odbyło się w dniach 15-16 marca 2017 r. w Strasburgu. Parlamentarny Komitet Stowarzyszenia, rozpatrując stan stosunków między Ukrainą a UE, wdrażanie Układu o stowarzyszeniu, ogólne bezpieczeństwo i sytuację polityczną na Ukrainie, uzgodnił ostateczne oświadczenie ${ }^{21}$.

Szóste posiedzenie Komitetu Parlamentarnego Stowarzyszenia odbyło się w dniach 19-20 września 2017 r. w mieście Dniepr. Przeprowadzono dyskusje na temat roli UE we wspieraniu odbudowy i rozwoju regionu oraz zapewnieniu podstawowych, codziennych potrzeb ludności. W końcowej rezolucji spotkania zadeklarowano: poparcie ukraińskich stanowisk na arenie międzynarodowej i potępienie agresywnej polityki ekspansjonistycznej Federacji Rosyjskiej, nieodpuszczenie do manipulowania dostępem do żołnierzy

\footnotetext{
${ }^{20}$ Parlamentskyi komitet asotsiatsii mizh Ukrainoiu ta EU ukhvalyv Zakliuchnu Zaiavu ta Rekomendatsii.

${ }^{21}$ Zakliuchna zaiava ta rekomendatsii Piatoho zasidannia Parlamentskoho komitetu asotsiatsii mizh Ukrainoiu ta Yevropeiskym Soiuzom.
} 
sił pokojowych przez Federację Rosyjską, kwestie gospodarcze, zapobieganie projektom szkodzącym gospodarce Ukrainy, Polski i innych państw (dotyczy North Stream 2), a także przepisy dotyczące sposobów zwalczania korupcji ${ }^{22}$.

Podczas siódmego posiedzenia Komitetu Parlamentarnego Stowarzyszenia (18-19 kwietnia 2018 roku w Strasburgu), omówiono sytuację bezpieczeństwa, konsekwencje rosyjskiej agresji i aneksji Krymu, realizację porozumień mińskich, pogarszającą się sytuację środowiskową we wschodniej Ukrainie, stan realizacji Układu o stowarzyszeniu, perspektywy dalszych relacji pomiędzy UE a Ukrainą, współpracy w sektorach gospodarczych i energetycznych, a także stan reform na Ukrainie w tym reformy sądownictwa, zwalczanie korupcji, reformy systemu wyborczego, zapewnienie ochrony praw człowieka, podstawowych wolności i niezależnych mediów ${ }^{23}$.

Ósme posiedzenie Komitetu Parlamentarnego Stowarzyszenia odbyło się w dniach 17-18 września 2018 r. we Lwowie oraz w Iwano-Frankowsku. Uczestnicy wyrazili głębokie zaniepokojenie dalszym pogorszeniem się sytuacji we wschodniej Ukrainie, wzrostem obecności wojskowej Rosji w regionie Morza Azowskiego i blokadą statków w wyniku budowy mostu kerczeńskiego. Podjęto decyzję o rozszerzeniu unijnych sankcji wobec Federacji Rosyjskiej i wyznaczeniu specjalnego wysłannika do rozwiązania sytuacji we wschodniej Ukrainie i na Krymie oraz uruchomieniu misji pokojowej ONZ na Donbasie. Komitet stwierdził, że należy uznać odpowiedzialność Federacji Rosyjskiej za zniszczenie samolotu linii Malaysia Airlines przez pocisk rakietowy Buk należący do rosyjskich sił zbrojnych, a także odpowiedzialność Federacji Rosyjskiej oraz nielegalnych formacji wojskowych za cierpienia obywateli w wyniku rosyjskiej agresji wojskowej. Wezwano nielegalne jednostki zbrojne tzw. Donieckiej Republiki Ludowej i Ługańskiej Republiki Ludowej do zapewnienia niezakłóconego i bezpiecznego dostępu dla wszystkich organizacji humanitarnych, a także dla Specjalnej Misji Monitorującej OBWE do całego terytorium tymczasowo niekontrolowanego przez rząd ukraiński. Niepokój powoduje pogorszenie się lokalnych konsekwencji rosyjskiej agresji wojskowej we wschodniej Ukrainie i na anektowanym Krymie. Strony wyraziły zaniepokojenie dalszym pogarszaniem stanu praw człowieka na Krymie, w szczególności Tatarów krymskich. Potępiono polityczne

${ }^{22}$ Zvit pro vykonannia Uhody pro asotsiatsiiu mizh Ukrainoiu ta EU (veresen 2014 roku sichen 2015 roku).

${ }^{23}$ Za rezultatamy Somoho zasidannia Parlamentskoho komitetu Asotsiatsii mizh Ukrainoiu ta EU ukhvaleno Zakliuchnu zaiavu ta rekomendatsii. 
prześladowanie obywateli ukraińskich nielegalnie zatrzymanych w Rosji i na okupowanym Krymie. Uczestnicy spotkania pokreślili również, że budowa North Stream 2 stanowi zagrożenie dla bezpieczeństwa europejskiego ${ }^{24}$.

Szczyt pozytywnie ocenił powołanie w Radzie Najwyższej Ukrainy Grupy Roboczej ds. reform, przedsięwzięcia mające na celu wzmocnienie zdolności instytucjonalnej i przyjęcie odpowiedniego ustawodawstwa, a także reformy mające na celu przekształcenie Rady Najwyższej Ukrainy w skuteczny, przejrzysty i efektywny organ prawodawczy, którego działania mają na celu zapewnienie reform, wdrożenie Układu o stowarzyszeniu. Przywódcy uznali, że należy kontynuować reformy antykorupcyjne i nadal wspierać działalność organów antykorupcyjnych. Podkreślono rolę niezależnych mediów oraz gwarantowano im prawo do prowadzenia dochodzeń w sprawach korupcji na szczeblu rządowym bez ryzyka prześladowania. Komitet wystąpił z apelem do Parlamentu Ukrainy o jak najszybsze zniesienie przepisów zobowiązujących działaczy społecznych zajmujących się zwalczaniem korupcji do wypełnienia deklaracji elektronicznych o dochodach. Podkreślono znaczenie zintensyfikowania rozwoju współpracy transgranicznej między Ukrainą a krajami UE oraz rozwoju infrastruktury przygranicznej, zwłaszcza w regionie karpackim.

Podkreślono znaczenie współpracy między Ukrainą a UE w dziedzinie komunikacji strategicznej i cyberbezpieczeństwa w celu zwalczania fałszywych wiadomości i propagandy rosyjskiej, przeciwstawienia się cyberatakom. Strony oczekują na zakończenie procedury formowania Centralnej Komisji Wyborczej i przyjęcia nowego kodeksu wyborczego w drugim czytaniu. Zaznaczono rolę Krajowej Agencji ds. Zapobiegania Korupcji w kontrolowaniu finansów partii i deklaracji o dochodach. Podkreślono, że władze ukraińskie powinny zwrócić większą uwagę na zapewnienie równości płci i walce z dyskryminacją ludzi, ochronę praw mniejszości narodowych i seksualnych ${ }^{25}$.

Należy zauważyć, że europejskie doświadczenie w zakresie ochrony praw mniejszości seksualnych nie cieszy się poparciem w społeczeństwie ukraińskim i postrzegane jest jako „propaganda rozpusty i sodomii”. Na stronie internetowej Prezydenta, Rady Najwyższej i Gabinetu Ministrów Ukrainy została zarejestrowana petycja elektroniczna, pod którą zebrano odpowiednią liczbę podpisów ${ }^{26}$. Jeśli UE „potępia przestępstwa z nienawiści wobec społeczności LGBT i wzywa władze ukraińskie do postawienia sprawców przed

${ }^{24}$ Za rezultatamy Vosmoho zasidannia Parlamentskoho komitetu asotsiatsii mizh Ukrainoiu ta EU ukhvaleno Zakliuchnu zaiavu ta rekomendatsii.

${ }^{25}$ Ibidem.

${ }^{26}$ Shchodo zakhystu tradytsiinykh simeinykh tsinnostei ta instytutu simi. 
wymiarem sprawiedliwości”, wówczas ukraińscy chrześcijanie protestują przeciwko narzuceniu Ukrainie, ich zdaniem, grzesznego stylu życia. Nawet najbardziej prozachodnia wśród tradycyjnych cerkwi - Ukraińska Cerkiew Greckokatolicka - zajęła kategoryczne stanowisko w tej kwestii:

Wszelkie próby popularyzacji lub legitymizacji rozpusty, sodomii i innych podobnych rodzajów grzesznych zachowań powinny skłonić polityków chrześcijańskich do natychmiastowego reagowania i czynnego sprzeciwu za pomocą wszelkich legalnych sposobów ${ }^{27}$.

Ten przykład pokazuje, że na Ukrainie istnieje duży ruch protestu przeciwko ideom genderowym oraz grupom LGBT. Może to stać na przeszkodzie politycznego stowarzyszenia Ukrainy z UE.

Wspólnym organem społeczeństwa obywatelskiego, w skład którego wchodzą przedstawiciele związków zawodowych, organizacji pracodawców, organizacji społeczeństwa obywatelskiego Ukrainy oraz przedstawiciele Europejskiego Komitetu Ekonomiczno-Społecznego (EKES), jest Platforma Społeczeństwa Obywatelskiego. Platforma może formułować zalecenia dla Rady Stowarzyszenia i powinna być informowana o decyzjach i zaleceniach Rady Stowarzyszenia. Przewiduje się, że Komitet Stowarzyszenia i Parlamentarny Komitet Stowarzyszenia będą regularnie kontaktować się z przedstawicielami Platformy Społeczeństwa Obywatelskiego w celu uzyskania ich opinii w sprawie osiągnięcia celów Układu o Stowarzyszeniu.

W trakcie posiedzeń Platformy Społeczeństwa Obywatelskiego, które odbyły się 16 kwietnia 2015 roku w Kijowie, 18 grudnia 2015 roku w Brukseli, 11 lutego 2016 r. w Brukseli, 8-9 listopada 2016 w Kijowie, 18 maja 2017 roku w Brukseli, omówiono następujące zagadnienia: stan wdrażania i realizacji przez Ukrainę Układu o stowarzyszeniu, reformy wewnętrzne, wzmocnienie współpracy gospodarczej, zaangażowanie społeczeństwa obywatelskiego w realizację programów i projektów unijnych, wojny we wschodniej Ukrainie, zapewnienie suwerenności i integralności terytorialnej Ukrainy, wspólne działania planistyczne, a także zatwierdzone zostały wspólne oświadczenia, deklaracje i zalecenia.

Na szóstym posiedzeniu Platformy Społeczeństwa Obywatelskiego UE-Ukraina, które odbyło się 12 kwietnia 2018 r. w Brukseli, omówiono kwestie związane $\mathrm{z}$ wdrażaniem Układu o stowarzyszeniu, rolą wynagrodzenia w ograniczaniu ubóstwa i jego wpływ na migrację zarobkową, a także zmiany klimatyczne w kontekście integracji europejskiej. Członkowie PSO we wspól-

\footnotetext{
${ }^{27}$ Poklykannia myrian do uchasti v suspilno-politychnomu zhytti krainy.
} 
nej deklaracji: z zadowoleniem przyjęli nowy rządowy plan działania dotyczący wdrożenia układu o stowarzyszeniu; wezwali Ukrainę do wycofania przepisów antykorupcyjnych, które wymagają od antykorupcyjnych organizacji pozarządowych i działaczy składania deklaracji o dochodach; uznali potrzebę konsekwentnego wdrażania reform w różnych obszarach, w tym w zakresie energii i efektywności energetycznej, zdrowia i administracji publicznej; potępili nielegalne wybory na Krymie, które odbyły się w marcu 2018 r.; wezwali do natychmiastowego uwolnienia wszystkich więźniów politycznych z Ukrainy i wszystkich nielegalnie przetrzymywanych w Rosji i na okupowanych terytoriach ${ }^{28}$.

\section{WNIOSKI}

Dialog polityczny w ramach Układu o stowarzyszeniu pozwala przywódcom Ukrainy i UE koordynować podejścia mające na celu wzmocnienie stowarzyszenia politycznego i integracji gospodarczej Kijowa i Brukseli, aby wspólnie reagować na strategiczne wyzwania w warunkach dynamicznych zmian na poziomie globalnym i regionalnym. Rezultatem komunikacji politycznej była ratyfikacja i wejście w życie układu o stowarzyszeniu, unijne wsparcie dyplomatyczne dla Ukrainy przeciwko agresji Rosji, utworzenie strefy wolnego handlu między Ukrainą a UE, wprowadzenie systemu bezwizowego i ważne kroki w celu przezwyciężenia zależności energetycznej Ukrainy od Federacji Rosyjskiej. Dzięki wdrożeniu Układu o stowarzyszeniu Ukraina przez 4 lata zrobiła więcej w dziedzinie reform niż przez poprzednie 20 lat.

Przeszkodami w komunikacji politycznej stają się następujące problemy Ukrainy: nieefektywne zwalczanie korupcji; nieskuteczna reforma systemu egzekwowania prawa i systemu sądownictwa; niestabilność ram prawnych; niestabilność systemu finansowego i bankowego; brak gwarancji ochrony praw własności potencjalnego inwestora; kwestia otwartości i swobodnego dostępu do rejestrów praw własności. Przeszkody te wynikają z: dominacji grup oligarchicznych, które nie są zainteresowane przeprowadzaniem głębokich reform demokratycznych $\mathrm{w}$ kraju, a także rozprzestrzeniania się paternalistycznych nastrojów w społeczeństwie ukraińskim, wykorzystywanych przez populistów w walce politycznej.

${ }^{28}$ Daidzhest novyn z yevrointehratsii, Yevropeiskoho Soiuzu ta Skhidnoho Partnerstva za 1 chervnia - 15 kvitnia $2018 \mathrm{r}$. 
Ukraina jest niezadowolona $\mathrm{z}$ niechęci UE do przyznania jej perspektywy członkostwa, nieskuteczności porozumień mińskich, których Rosja nie wypełnia, a także wysiłków poszczególnych państw i firm europejskich w celu obejścia sankcji nałożonych na Federację Rosyjską. UE ignoruje faktyczną sytuację Ukrainy, przeciwko której Rosja rozpoczęła „wojnę hybrydową”, i nalega na liberalne reformy, które mogą rozpraszać siłę i osłabiać możliwości Ukrainy silnego przeciwstawiania się rosyjskiej agresji. Na Ukrainie powstaje ruch obrony tradycyjnych wartości rodzinnych i instytucji rodziny, oponujący wobec ochrony praw mniejszości seksualnych i społeczności LGBT (odpowiednie petycje uzyskały poparcie obywateli ukraińskich na stronach internetowej Prezydenta, RNU i KMU). Jednocześnie pomoc UE dla Ukrainy ogranicza się do sankcji wobec Rosji i wsparcia dyplomatycznego, co jest niewystarczające, gdy Rosja stosuje siłę militarną. UE odmawia udzielenia Ukrainie odpowiedniej pomocy wojskowej i finansowej, która pozwoliłaby przeciwdziałać rosyjskiej agresji.

Problemy, takie jak korupcja, rządy oligarchów, bezskuteczne reformy, kosmetyczne zmiany w państwie ukraińskim, rosyjska agresja, brak jednoznacznego stanowiska UE w kwestii europejskich perspektyw Ukrainy i sankcji wobec Rosji, odrzucenie przyznania Ukrainie pomocy wojskowej i finansowej, ignorowanie przez UE sytuacji na Ukrainie, która prowadzi „wojnę hybrydową" z Rosją, frustracja ludzi, znaczny spadek poziomu życia po rewolucji godności i zmęczenie wojną, mogą stanąć na przeszkodzie realizacji stowarzyszenia politycznego między Ukrainą a UE.

W takich okolicznościach Ukraina powinna: zrezygnować z przystąpienia do UE; skonsolidować społeczeństwo wokół idei narodowej, która oferuje duchowy paradygmat rozwoju Ukrainy; przeprowadzić modernizację ukraińskiego państwa i społeczeństwa, korzystając z mechanizmów przewidzianych $\mathrm{w}$ układzie stowarzyszeniowym (stowarzyszenie polityczne oraz kompleksowa i pogłębiona strefa wolnego handlu); krytycznie przemyśleć i przejąć tylko pozytywne europejskie doświadczenie zgodnie z potrzebami i obiektywnymi warunkami historycznymi. 


\section{MECHANISMS FOR INTENSIFYING POLITICAL COMMUNICATION BETWEEN UKRAINE AND THE EU WITHIN THE FRAMEWORK OF THE ASSOCIATION AGREEMENT}

\section{Summary}

Successful implementation of the Association Agreement and the formation of the political association depend directly on the political communication between Ukraine and the EU, but the problem remains largely unexplored in domestic science. Therefore, the article aims to examine that crucial aspect and identify communication-related issues which can hinder European integration of Ukraine.

Political communication between Ukraine and the EU takes place within the framework of the Ukraine-EU summits, Association Council, Association Committee, Parliamentary Committee of the Association and the EU-Ukraine Civil Society Platform.

At the summits, political communication is conducted at the highest level of representation. During the summits, the parties engage in general supervision over the implementation of the Agreement, and discuss of any bilateral or international issues of mutual interest.

The Association Council monitors and controls the implementation of the Agreement, periodically reviews the functioning of the Agreement in the context of its goals as well addresses issues that arise under this Association. The Association Council holds ministerial-level meetings.

The Association Committee assists the Association Council in carrying out its duties. On the Ukrainian side, members of the Association Committee include deputy ministries for European integration, Deputy Minister of Economic Development and Trade - Trade Representative of Ukraine, deputy heads of other central executive bodies, whose powers encompass the implementation of the Agreement. The competence of the Committee is to prepare meetings of the Association Council. In addition, the Council may delegate any of its powers to the Association Committee, including the power to take binding decisions for the Parties. The Association Committee prepares its decisions with the consent of the Parties. The Association Committee holds special meetings to solve all the questions to ensure the functioning of a comprehensive and deep free trade area between Ukraine and the EU.

The Parliamentary Committee of the Association is a forum for conducting meetings and exchanging views between members of the Verkhovna Rada of Ukraine and the European Parliament. It includes deputies of the Verkhovna Rada of Ukraine and the European Parliament. This body has the right to ask the Associa- 
tion Council to provide information on the implementation of the Association Agreement and to give its own recommendations, as well as create appropriate subcommittees.

The Civil Society Platform is a joint civil society body composed of representatives of trade unions, employers' organizations, civil society organizations of Ukraine and representatives of the European Economic and Social Committee. The Civil Society Platform may make recommendations to the Association Council, and should be informed about the decisions and recommendations of the Association Council.

Political communication within the framework of the Association Agreement allows Ukrainian and EU leaders to agree on and coordinate their approaches to strengthen political association and economic integration between Kiev and Brussels, as well as jointly respond to strategic challenges in conditions of dynamic changes at global and regional levels. Political communication resulted in the ratification and entry into force of the Association Agreement, EU diplomatic support against the aggression of Russia, establishment of the free-trade zone between Ukraine and the EU and the free-trade area between Ukraine and the EU, a visa-free regime, not to mention the important steps taken to overcome Ukraine's energy dependence on the Russian Federation. Following the implementation of the Association Agreement, Ukraine has implemented more reforms over the last 4 years than it did in the previous two decades.

\section{Bibliografia}

Daidzhest novyn z yevrointehratsii, Yevropeiskoho Soiuzu ta Skhidnoho Partnerstva za 1 chervnia - 15 kvitnia 2018 r. [online]. Ukrainska Asociacija Inwestycijnoho biznesu [dostępny: 2018-04-20]. Dostępny w Internecie: <http://www.uaib.com.ua/aktual_kua/euro/news_ digest/265615.html>.

Daidzhest novyn z yevrointehratsii, Yevropeiskoho Soiuzu ta Skhidnoho Partnerstva za 26 chervnia - 15 lypnia 2018 r. [online]. Ukrainska Asociacija Inwestycijnoho biznesu [dostęp: 2018-07-15]. Dostępny w Internecie: <http://www.uaib.com.ua/aktual_kua/euro/news_digest/ 267932.html>.

Daidzhest novyn z yevrointehratsii, Yevropeiskoho Soiuzu ta Skhidnoho Partnerstva za 1-25 hrudnia 2017 r. [online]. Płatforma Hromadjanśkoho suspilstwa Ukrajina-JS [dostęp: 2017-12-25]. Dostępny w Internecie: <http://eu-ua-csp.org.ua/news/117-digest-12>.

Krasiwski O. 2016, Podstawowe zagadnienia integracji europejskiej. Ukraina a Unia Europejska, red. tomu K. Jędraszczyk, Gniezno, s. 175-230.

Uhoda pro asotsiatsiiu mizh Ukrainoiu, $\mathrm{z}$ odniiei storony, ta Yevropeiskym Soiuzom, Yevropeiskym spivtovarystvom $\mathrm{z}$ atomnoi enerhii i yikhnimy derzhavamy-chlenamy, $\mathrm{z}$ inshoi storony [online]. Rada [dostęp: 2015-11-30]. Dostępny w Internecie: <http:// zakon3.rada.gov.ua/laws/show/984_011>.

Opublikovano tekst rishennia EU shchodo Uhody pro asotsiatsiiu z Ukrainoiu, z urakhuvanniam pozytsii Niderlandiv [online]. UA [dostęp 2016-09-16]. Dostępny w Internecie: 
$<$ https://ua.112.ua/statji/opublikovano-tekst-rishennia-yes-shchodo-uhody-pro-asotsiatsiiuz-ukrainoiu-z-urakhuvanniam-pozytsii-niderlandiv-359551.html>.

Rishennia № 3/2014 Rady asotsiatsii mizh Ukrainoiu ta EU vid 15 hrudnia 2014 r. pro delehuvannia radoiu asotsiatsii okremykh povnovazhen Komitetu asotsiatsii u torhovelnomu skladi [online]. Ministerstwo Zakordonnych Spraw Ukrajiny [dostęp: 2014-12-15]. Dostępny w Internecie: <http://zakon2.rada.gov.ua/laws/show/845_003>.

Ruda O. 2015, Pro szczo domowyłysia na Samiti Uraina-JS [online]. Zaxid [dostęp: 2015-04-25]. Dostępny w Internecie: <https://zaxid.net/pro_shho_domovilis_na_samiti_ukrayinayes_ n1349427>.

Parlamentskyi komitet asotsiatsii mizh Ukrainoiu ta EU ukhvalyv Zakliuchnu Zaiavu ta Rekomendatsii [online]. Werchowna Rada Ukrajiny [dostęp:2016-05-04]. Dostępny w Internecie: <http://rada.gov.ua/news/Novyny/129472.html >.

Pidsumky samitu Ukraina-JS, „RBK - Ukrajina” [online]. RBC [dostęp 2016-11-24]. Dostępny w Internecie: <https://daily.rbc.ua/ukr/show/itogi-sammita-ukraina-es-2016-1480014052. html>.

Poklykannia myrian do uchasti v suspilno-politychnomu zhytti krainy: dushpastyrskyi poradnik, Ukrainska Hreko-Katolytska Tserkva, 2018.

Pytannia pidhotovky ta provedennia zasidan okremykh dvostoronnikh orhaniv asotsiatsii mizh Ukrainoiu ta EU: Postanova Kabinetu Ministriv Ukrainy vid 10 hrudnia $2014 \mathrm{r}$. № 700 [online]. Rada [dostęp"2017-10-31]. Dostępny w Internecie: <http://zakon3.rada. gov.ua/laws/show/700-2014-\%D0\%BF>.

Ukrainoiu Spilnyi pres-reliz pislia zustrichi Rady asotsiatsii mizh Yevropeiskym Soiuzom i (07/12/2015) [online]. Ministerstwo Zakordonnych Spraw Ukrajiny [dostęp: 2015-12-09]. Dostępny w Internecie: <https://www.kmu.gov.ua/storage/app/media/uploaded-files/ spilniy-pres-reliz07-12-15.pdf >.

Spilnyi pres-reliz pislia zustrichi Rady asotsiatsii mizh Yevropeiskym Soiuzom i Ukrainoiu (16/12/2016) [online]. Ministerstwo Zakordonnych Spraw Ukrajiny [dostęp: 2016-12-19]. Dostępny w Intermecie: <https://mfa.gov.ua/ua/press-center/news/53311-spilynij-presreliz-za-pidsumkami-tretyogo-zasidannya-radi-asociaciji-ukrajina-jes $>$.

Shchodo zakhystu tradytsiinykh simeinykh tsinnostei ta instytutu simi: elektronna petytsiia Verkhovnii Radi Ukrainy [online]. KMU [dostęp:2018-05-25]. Dostępny w Internecie: $<$ https://petition.kmu.gov.ua/m/Petition/View/1485>.

Zakliuchna Zaiava ta Rekomendatsii Pershoho zasidannia Parlamentskoho komitetu asotsiatsii Ukraina - EU [online]. Komitet z pytań jewropejśkoji intehracii [dostęp: 2015-02-26]. Dostępny w Internecie: <http://comeuroint.rada.gov.ua/news/International/International_ PAC/International_PAC_activity/72559.html>.

Zakliuchna Zaiava ta Rekomendatsii Pershoho zasidannia Parlamentskoho komitetu asotsiatsii Ukraina-EU. http://comeuroint.rada.gov.ua/news/International/International_PAC/ International_PAC_activity/72559.html>.

Zakliuchna Zaiava ta Rekomendatsii Druhoho zasidannia Parlamentskoho komitetu asotsiatsii Ukraina EU [online]. Ministerstwo Zakordonnych Spraw Ukrajiny [dostęp: 2017-11-05]. Dostępny w Internecie: <mfa.gov.ua/ua/press-center/news/41761-zaklyuchna-zajava-tarekomendaciji-drugogo-zasidannya-parlamentsykogo-komitetu-asociaciji-mizhukrajinoju-ta-jes>.

Za rezultatamy Somoho zasidannia Parlamentskoho komitetu Asotsiatsii mizh Ukrainoiu ta EU ukhvaleno Zakliuchnu zaiavu ta rekomendatsii. [online]. Werchowna Rada Ukrajiny [dostęp:2018-04-23]. Dostępny w Internecie: <http://rada.gov.ua/fsview/157504.html>.

Za rezultatamy Vosmoho zasidannia Parlamentskoho komitetu asotsiatsii mizh Ukrainoiu ta EU ukhvaleno Zakliuchnu zaiavu ta rekomendatsii. [online]. Werchowna Rada Ukrajiny [dostęp:2018-09-20]. Dostępny w Internecie: <http://www.rada.gov.ua/news/Novyny/162272. html>. 
Zakliuchna zaiava ta rekomendatsii Piatoho zasidannia Parlamentskoho komitetu asotsiatsii mizh Ukrainoiu ta Yevropeiskym Soiuzom. [online]. Werchowna Rada Ukrajiny [dostęp: 2017-03-22]. Dostepny w Internecie: <http://iportal.rada.gov.ua/news/Novyny/141979.html>.

Zvit pro vykonannia Uhody pro asotsiatsiiu mizh Ukrainoiu ta EU (veresen 2014 roku - sichen 2015 roku) [online]. KMU [dostęp: 205-03-12]. Dostępny w Internecie: <https://www. kmu.gov.ua/storage/app/media/zviti-proikonannya/AA_impl_report_02_2015_GOEI.pdf>.

4-5 lystopada u Kyievi vidbulos Druhe zasidannia Parlamentskoho komitetu asotsiatsii mizh Ukrainoiu ta EU [online]. Komitet z pytań jewropejśkoji intehracii [dostęp: 2015-11-05]. Dostępny w Internecie: <http://comeuroint.rada.gov.ua/news/International/International_ PAC/International_PAC_activity/72675.html>.

19-j Samit Ukraina Yevropeiskyj Sojuz [online]. Ministerstwo zakordonnych spraw Ukrajiny [dostęp 2017-07-13]. Dostępny w Internecie: <https://mfa.gov.ua/ua/page/open/id/5114>. 